\title{
PENGGUNAAN BAHASA VERBAL HIPNOTERAPIS DAN PENGARUH NONVERBAL TERHADAP PECANDU ROKOK: SUATU KAJIAN NEUROSPIKOLINGUISTIK
}

\author{
Fetri Reni, SS., M.Hum. \\ Volume 1 Nomor 1 \\ JIPS ISSN: 2579-5449
}

\begin{abstract}
This research is aimed at finding the suggestion forms of verbal hypnoterapist language and its nonverbal reaction to cigarette suffering (clients). In collecting data is used observation method and non-Participant observation technique followed by recording and note taking method. The data is collected at one of hypnoteraphy clinic in Padang. In analyzing the data, the writer uses referential and pragmatic identity method. To finding data clearly, valuable, and easy to read is used descriptive statistic in order to know client condition and how far verbal hypnotherapist can influent to the client. Data is served in the formal and informal method. Based on the analysis is concluded that, somnabulistic is an important section in giving hypnotherapy suggestion. Using word "belatung" to AM client, "tikus" to WW client, and "ular" to IR client have a different

reaction to each client. Client AM in the 21-27 scale, is a good suggestion. He is a Physical Sugestible who has right hemisfer domain. Client WW is an Emotional Sugestible, in the 21-27 also but she has dificulty in the open eyes trance, she is a middle suggestion who has left hemisfer domain and client IR has Intelectual Sugestible, who has critical analysis, in the 2835 . Beside that suggestions must have given reapeatly short, clear and motivation understandable langguage. Suggestions are in the plural and active sentences which avoid in using words "dont", "will", "no".Overall, cigarette suffering is a person who suffer from unconsious mind or psychomatis that can give negative effect to his healhty. Giving suggestion motivation sentences in hypnotherapy can hamper the critical factor of client and finally, can solve client suffer problems.
\end{abstract}

\section{Keywords: Hypnotherapy Language, Nonverbal Reaction, Cigarette Suffering, Neurospycholinguistic.}




\begin{abstract}
ABSTRAK
Penelitian ini bertujuan untuk Physical Sugestible yaitu orang yang dominan menemukan bentuk-bentuk sugesti yang otak kanan. Klien WW pada skala 2127, diberikan hipnoterapis terhadap kliennya yaitu berteriak histeris dengan mimik wajah ketakutan, pecandu rokok dan reaksi yang ditimbulkan mengalami kesulitan pada trans dengan mata terhadap bahasa yang diberikan. Pengumpulan terbuka yang termaksud kategori sugesti sedang, data dilakukan dengan metode simak yaitu, disebut juga dengan Emotional Sugestible yaitu penyedian data penelitian ini dilakukan dengan dominan otak kiri. Sementara klien IR adalah penyimakan terhadap pemakaian bahasa pada kategori sugesti buruk, somnabulistik terjadi salah satu klinik hipnoterapi Padang dan teknik pada skala 28-35, dengan mimik wajah seperti Simak Libat Cakap serta teknik catat. Metode ketakutan atau disebut juga dengan Intelektual yang digunakan untuk menganalisis data adalah Sugestible yang memiliki pola pikir kritis. Selain metode padan referensial dan padan pragmatik. kata inti, sugesti harus disampaikan berulang, Penyajian hasil analisis disajikan secara metode jelas, singkat dan mudah dipahami, berisi formal dan informal.Berdasarkan hasil analisis motivasi dan kepastian, sugesti merupakan data, diperoleh simpulan bahwa pemberian kalimat tunggal (tidak kiasan), kalimat aktif sugesti pada tahap Suggestion yaitu disaat klien dengan menghindari kata-kata "jangan", "akan", telah memasuki kondisi Somnabulistik (trans dalam) dengan menggunakan kata "belatung" pada klien AM, "tikus" pada klien WW dan "ular" pada klien IR, terjadi reaksi pada skala yang berbeda-beda. Klien AM pada skala 21-27, terlihat mimik wajah seperti jijik dan ketakutan, bahasa verbal hipnoterapis kepada pecandu rokok dapat berpengaruh kepada gelombang otak, pikiran sadar dan bawah sadar, dan pikiran kritis (Critical Factor) yang pada akhirnya akan dapat mengatasi masalah yang dialami klien.
\end{abstract} kategori sugesti baik atau disebut juga dengan

\title{
Kata Kunci: Bahasa Hipnoterapis, Reaksi Nonverbal, Pecandu Rokok, Neurospikolinguistik
}

\section{PENDAHULUAN}

Secara ilmiah, mekanisme kerja otak berpengaruh terhadap sistem syaraf dan perilaku seseorang. Kecendrungan seseorang untuk berpikir dan beraktivitas berhubungan dengan otak. Otak manusia adalah organ yang unik dan dasyat. Otak merupakan tempat diaturnya proses berpikir, berbahasa, kesadaran, emosi, dan kepribadian.
Ketika seseorang menggunakan katakata, ia telah menyederhanakan sebuah pengalaman yang kompleks, banyak informasi yang tidak diikutsertakan atau hilang (deletion) atau karena tidak dapat mengingatnya dengan baik. Kata-kata yang digunakan dalam menjelaskan sebuah pengalaman juga tidak sama dengan kenyataannya (distortion), dan kita juga 
menyamaratakan aturan yang berlaku pada satu contoh sebagai aturan yang berlaku pada berbagai konteks.

Terciptanya persamaan makna akan memberikan pengaruh yang cukup besar bagi hubungan antar individu sebagai pendengar dan yang terlibat dalam komunikasi. Adanya pengaruh yang besar bagi pelaku tuturan merupakan langkah awal dalam menuju sugesti yang pada akhirnya akan menimbulkan proses pemberiaan sugesti pada tingkat tinggi yang disebut hipnotis.

Hipnotis dalam prosesnya berhubungan dengan fungsi berpikir. Hipnotis juga dapat mempengaruhi fungsi otak lainnya karena fungsi ini saling berinteraksi. Di dalam jaringan hidup otak manusia terdapat gelombang listrik yang berfluktuasi. Menurut penelitian, sensasi yang dirasakan di otak tergantung dari gelombang otak. Gelombang otak di saat rileks, konsentrasi, melamun, maupun mabuk adalah berbeda-beda.

Fenomena hipnotis sudah lama dikenal dalam kehidupan sehari-hari. Tampa disadari, seseorang telah memasuki keadaan itu sendiri, seperti ketika kita menonton film, secara tidak langsung, kita telah terhipnotis ketika merasakan ketegangan ketika melihat keseruan sebuah film, tertawa terbahak-bahak bahkan menangis, seorang ibu menidurkan anaknya dengan mengelus kepala, menepuk-nepuk dengan lembut, menidurkan dalam ayunan. Semua tindakan itu sudah merupakan tindakan hipnotis. Hipnotis merupakan suatu keahlian untuk "memasukkan" pesan ke dalam diri seseorang, sehingga yang bersangkutan akan bergerak atau termotivasi untuk melaksanakan pesan yang dimaksud. Pesan yang dimaksudkan adalah rangkaian kalimat verbal (kalimat yang diucapkan secara lisan) yang akan "masuk" ke penerima melalui telinga dan kemudian akan memasuki "hati". Selanjutnya, "hati" akan tergerak untuk melakukan sesuatu yang dimaksudkan oleh pihak yang melakukan hipnotis.

Dalam pengetahuan hipnotis moderen, yang dimaksud dengan "hati" adalah sesuatu yang disebut sebagai "pikiran bawah sadar", tempat di mana motivasi berada. Secara keseluruhan, hipnotis merupakan proses yang membawa seseorang untuk memasuki alam bawah sadar melalui pemahaman kata-kata yang disusun menjadi sebuah sugesti. Pikiran bawah sadar manusia memiliki "pintu gerbang" yang dapat terbuka dan tertutup, dengan mekanisme yang dikontrol oleh berbagai hal, gerbang ini dapat terbuka dengan sendirinya. Informasi atau saran akan masuk secara mudah apabila bahasa yang digunakan hipnoterapis dapat dimengerti sebaliknya, saat tertutup maka informasi tidak akan dapat memasuki pikiran bawah sadar. Adapun contoh bentuk tuturan bahasa verbal hipnotis untuk relaksasi (ketenangan):

Tutup mata anda dan buatlah diri anda dalam kondisi rileks... Tarik napas anda yang dalam... Hembuskan... Tarik napas lagi...dan hembuskan... Tarik napas lagi... Tahan beberapa detik... Hembuskan serta rileks...

Saya akan membuat anda jadi rileks... setiap bagian tubuh anda dari ujung kepala sampai ujung kaki anda... dan pada saat anda membuat rileks setiap bagian tubuh anda... saya ingin anda untuk berimajinasi... lihat yang anda lihat... rasakan yang anda rasakan... ketika tubuh anda menjadi rileks seluruhnya... dimulai dari ubun-ubun kepala anda... kulit kepala anda dan kening anda... alis mata anda dan kedua kelopak mata anda... dan anda merasakan releksasi itu menyebar hingga pipi dan hidung anda... anda rasakan releksasi itu hingga ke bibir anda dan khususnya otot sekitar mulut dan bibir Anda... pastikan bibir anda tidak perlu merapat... dan relekskan saja... releksasi itu menyebar hingga kedagu dan rahang anda... dan biarkan seluruh otot dimuka anda begitu santai luar biasa... dan rasakan rileksasi itu menyebar ke leher anda... turun ke bahu.. rasakan betapa bahu anda sangat rileks... luar biasa rileks...

Biarkan seluruh ketegangan di bahu dan leher anda hilang begitu saja... dan rileksasi itu menyebar hingga kedua tangan anda...mulai dari bahu siku dan pergelangan tangan anda... ke tangan 
anda... menyebar ke jari-jari anda... begitu rileksnya dan santai...

Perhatikan napas anda menjadi dalam dan tenang... rasakan napas anda... rasakan irama dari napas anda... setiap tarikan dan hembusannya begitu santai... rasa santai dan rileks itu menyebar ke dada anda... sangat rileks... lalu biarkan menyebar ke perut anda... biarkan otot di sekitar perut anda begitu santai...

Sebarkan rasa rileks itu ke paha ... betis... kaki... dan pergelangan kaki anda... begitu rileksnya... bahkan menyebar hingga ke tapak kaki... ke ujung jari... begitu rileks dan sangat rileks...

Saat anda masuk dalam kondisi rileks yang sangat dalam... biarkan diri anda santai dan nyaman... biarkan pikiran dan tubuh anda menjadi satu... rasakan betapa enaknya dan santainya perasaan ini...

Sekarang saya akan menghitung dari angka 5 ke angka $1 \ldots$ anda bayangkan diri anda seperti ada di atas awan... 5 tubuh anda seperti diselimuti awan... benar-benar seperti telah diselimuti dengan baik dengan selimut rileksasi ini... 4... luar biasa santai dan nyaman... sangat nyaman... 3... imajinasikan dari kepala anda... tubuh anda diselimuti awan rileksasi... 2... paha dan kaki diselimuti seluruhnya... dan $1 \ldots$ anda sudah benar-benar diselimuti dengan awan rileksasi yang sangat nyaman dan santai... (Arif, 2011)

Dari contoh penggunaan bahasa verbal hipnotis di atas, hipnoterapis mengarahkan dan menggiring imajinasi klien secara terarah dan beraturan sehingga klien bisa dengan mudah mengikuti saran dan arahan dari hipnoterapis. Penerimaan hipnotis ini akan berjalan dengan baik apabila kedua belah pihak dapat bekerjasama dengan baik. Klien dapat menerima dengan baik arahan dari hipnoterapis dan sebaliknya, hipnoterapis harus dapat juga menyusun kalimat arahan dengan benar, berurutan, dan jelas.
Hipnoterapi merupakan suatu bagian dari hipnotis yang digunakan untuk menerapi masalah-masalah seperti: gangguan emosi, luka batin, histeria, penyembuhan rohani, fobia, efek plasebo obat, dan kebiasaan-kebiasan buruk seperti, merokok, narkoba, alkohol, dan lain sebagainya. Mengingat banyaknya manfaat hipnoterapi dalam bidang kesehatan serta kejiwaan, maka dalam penelitian ini penulis membatasi penelitian terhadap pecandu rokok karena hampir sebagian masyarakat Indonesia $(70 \%)$ terutama kaum pria mengalami kecanduan ini (Survei Sosial Ekonomi Badan Pusat Statistik, 2001).

Pada pecandu rokok terjadi konflik antara pikiran sadar dan pikiran bawah sadar. Kebiasaan untuk merokok merupakan hasil pikiran bawah sadar sementara keinginan untuk berhenti merokok merupakan hasil logika pikiran sadar karena jelas merokok merugikan kesehatan dan ekonomi. Kecanduan merupakan suatu kebiasaan yang sudah tertanam kuat di pikiran bawah sadar. Dengan hipnoterapi, masalah ini dapat diatasi yaitu dengan pemberian sugesti melalui hipnotis.

Salah satu metode yang dikembangkan untuk melihat peranan bahasa dan pengaruhnya ke dalam pikiran adalah "Neuro Linguistik Program" (NLP) (Bandler dan Grinder, 1975). Metode ini merupakan sebuah model yang memprogram interaksi antara pikiran dan bahasa (verbal dan nonverbal) sehingga dapat menghasilkan pikiran dan perilaku yang diharapkan. NLP mempelajari pola-pola atau pemprograman yang diciptakan dari hubungan otak (neuro), bahasa (linguistik) dan kondisi tubuh (body state). Dengan menggunakan metode ini, dapat diketahui bentuk-bentuk bahasa verbal hipnoterapis dan reaksi nonverbal yang ditimbulkan akibat pemberian bahasa tersebut.

Dalam penelitian ini, penulis menggunakan pendekatan Neuro-Psikolinguistik yang merupakan gabungan dari kajian neurologi, psikologi, dan linguistik itu sendiri. Kajian ini dipilih karena dalam pemberian hipnoterapi, sugesti diberikan dengan tujuan mempengaruhi pikiran alam bawah sadar (neuro) klien yang 
diharapkam juga akan merubah sikap maupun

\section{HASIL DAN PEMBAHASAN}

Komunikasi terapeutik dilakukan juga untuk mengetahui produk sosial budaya dimana klien hidup dan bertumbuh, pernyataan ini sesuai dengan pendapat Hibdo (1974) menyatakan bahwa komunikasi terapeutik memungkinkan klien menemukan siapa dirinya. Dalam sesi ini dituntut kehati-hatian dari hipnoterapis dalam mendengarkan jawaban dari klien dan menanggapinya dengan cermat agar tidak terjadi ketimbangan dalam melihat dunia klien dengan kata lain, hipnoterapis dapat mengerti apa yang dipikirkan klien.

Dengan mengajukan pertanyaan yang terstruktur, akan menolong klien memandang utuh apa yang dipikirkan sehingga klien bisa lebih memberdayakan dirinya. Dibawah ini merupakan analisis suatu prasangka pikiran yang dialami klien:

1. Hip :"Ceritakan saja siapa tau saya bisa bantu".

AM : "...Saya dimarahi ibu"

Hip :"Dapatkah ibu menceritakan kecemasan yang ibu hadapi?".

WW : "...anak-anak saya sering

komplain tentang

masalah ini, saya merasa malu".

Dengan memberikan pertanyaan didalam

kalimat permintaan seperti diatas, dapat dilihat AM dan WW berpikir dalam suatu prangka bahwa AM mempunyai pikiran bahwa ibunya marah kepadanya, sementara klien WW berpikir anak-anaknya kurang simpati kepadanya dan ini akan mempengaruhi apa yang mereka pikirkan. Seorang hipnoterapis yang terlatih akan bisa menangkap apa yang dipikirkan oleh kliennya.

Didalam perilaku verbal (bahasa lisan) klien, akan terlibat juga perilaku nonverbalnya, atau perilaku nonverbal tidak muncul secara acak melainkan berada dalam setiap elemen helping relationship artinya, klien terus saja menghadirkan perilaku nonverbal bersamaan dengan verbalnya. Bahasa lisan (verbal) mungkin saja bertentangan dengan perilaku nonverbal dan mungkin juga perilaku nonverbal tersebut mendukung atau menekankan bahasa lisannya. Seperti dari ekpresi kecemasan yang ditunjukkan klien.

2. Hip :"Ceritakan saja, siapa tau saya bisa bantu"

AM (V) : "Saya dimarahin ibu saya pak, karena

ketahuan saya merokok pak"

(NV) : cemas dan sedih.

Hip : "Maaf, apakah anda merokok?"

IR (V) : "Iya pak, setelah saya konsultasi dengan

dokter, dokter menyatakan ada masalah

pada paru-paru saya.

(NV) : cemas dan sedih.

Hip: "Dapatkah ibu

menjelaskan kecemasan

yang ibu hadapi?"

WW (V) : "Saya merasa takut, cemas dan bersemangat."

(NV) : menatap hipnoterapis, menunduk dan wajah mulai cemas

Mengamati perilaku verbal dan nonverbal diatas, jika tidak diamati hipnoterapis secara bersungguh-sunguh maka besar kemungkinan pemberian hipnoterapi akan gagal dan klien tidak yakin pada hipnoterapi karena didalam pemberian hipnoterapi salah satu faktor keberhasilannya adalah keyakinan klien kepada hipnoterapis. Agar didapat umpan balik dari klien, hipnoterapis harus dapat menunjukkan suatu penerimaan, permintaan dalam memantulkan perasaan empati dan memberikan suatu pemikiran serta memberikan suatu informasi kepada kliennya. Hipnoterapis mempersilakan klien mulai menjelaskan masalah yang ingin dibicarakan:

3. "Ada yang bisa saya bantu? 
"Katakan apa yang memberatkan hatimu

"Kiranya ada sesuatu yang ingin anda bicarakan dengan saya?

Hipnoterapis menyatakan pengertian terhadap hal yang terungkap oleh klien:

4. "Saya mengerti" "Ya, ya...; sekaligus klien dipersilakan untuk meneruskan

pembicaraannya,

Dengan ungkapan "ya" disini hipnoterapis bukan bermaksud menyetujui apa yang dikatakan klien atau sepaham apa yang dikatakan klien tetapi hipnoterapis mencoba untuk memahami apa yang dirasakan oleh klien (empati).

5. WW: "Waduuuhhh... racun semua ya pak"

Hip: “ Ya, racun semua. Tidak ada yang menyehatkan, merokok

juga dapat menimbulkan kanker paruparu..."

Dalam hal ini hipnoterapis memantulkan kembali perasaan tentang, atau kejadian atau pengalaman yang diungkapkan secara verbal atau nonverbal kepada klien secara jelas dan eksplisit. Pemantulan perasaan ini dirumuskan dalam bentuk "restatement" atau dalam bentuk "paraphrase".

$\begin{array}{crr}\text { Menjelaskan pikiran, } & \text { gagasan,atau } \\ \text { klarifikasi pikiran, disini } & \text { hipnoterapis }\end{array}$ menjelaskan maksudnya agak tentatif atau menduga-duga, karena itu hipnoterapis memberikan umpan balik kepada klien untuk mengetahui apakah yang dimaksud hipnoterapis disini memang tepat:

6. "Betulkah demikian?"

"Apakah ibu ingin mengatakan......"

"Apakah saya menangkap maksud anda dengan benar?"

Penjelasan perasaan atau klarifikasi, yang menyangkut komponen efektif dalam pesan klien. Hipnoterapis mengadakan perception check dengan menggunakan paraphrase.

Permintaan untuk melanjutkan. Hipnoterapis mempersilakan klien untuk memberikan ulasan lebih lanjut tentang sesuatu yang telah dikemukakannya. Pengulangan satudua kata, dalam hal ini hipnoterapis mengulangi satu-dua kata kunci dalam kalimat tanya, tujuannya agar klien dapat menjelaskan persoalannya lebih lanjut. Selanjutnya hipnoterapis dapat memilih kata-kata yang lebih mengungkapkan pikiran atau gagasan yang lebih mengungkapkan pikiran atau gagasan yang lebih menggambarkan tentang perasaan.

Secara singkat dan dalam garis besar, hipnoterapis merumuskan apa yang telah dikatakan mengenal bagian penting terapi. Ada empat kemungkinan yaitu:

a. Pikiran dan gagasan yang telah dikemukakan oleh hipnoterapis, b. Sejumlah perasan yang telah diungkapkan oleh hipnoterapis, c.Inti pembicaraan antara hipnoterapis dan klien, d. Inti pembicaraan selama wawancara (ringkasan pada akhir wawancara).

Pertanyaan mengenai hal tertentu. Hipnoterapis menanyakan tentang hal tertentu, misal:

7. "Siapa ............?"
"Dengan maksud apa?"
"Apa yang............?"

Kalimat pertanyaan ini dapat menjadi pertanyaan terbuka atau pertanyaan tertutup, namun lebih baik dipertanyaan terbuka biar tidak terjadi kesalahpahaman didalam mengambil suatu kesimpulan.

Pemberian umpan balik terhadap keadaan seseorang disampaikan kepada klien tentang bagaimana ungkapannya, sikapnya, tindakannya, yang kemudian ditafsirkan oleh orang lain. Selanjutnya hipnoterapis menyampaikan pikiran, perasaannya mengenai sikap klien selama wawancara:

8. WW: "Maksud bapak, apakah kalau saya masih terus berlanjut merokok..."

Hip: "Bagus, ini adalah pertanyaan yang membawa ibu maju selangkah!"

Pemberian informasi, dimana hipnoterapis dapat menyampaikan pengetahuan tentang sesuatu, dalam hal ini tentang bahaya dan kerugian dari merokok kepada kliennya. Sesuatu yang sebaiknya diketahui klien, namun ternyata belum diketahuinya dan penyampaian ini tidak mengandung unsur saran.

Penyajian alternatif. Hipnoterapis mengemukakan beberapa alternatif yang disuguhkan kepada klien, dan klien diminta 
untuk memilih salah satu alternatif yang kemungkinan dapat diambil atau dilakukan. Kalimat ini dapat dilihat dari percakapan hipnoterapis dengan klien IR

9. Hip: "Tujuan anda kemari pasti ingin sembuh kan?, karena anda

masih mencintai hidup anda, mari kita saling

bekerjasama..."

Dalam penyelidikan ini, hipnoterapis melakukan inventarisasi alternatif-alternatif yang ada, memperkirakan segala akibat yang dapat timbul jika alternatif tertentu dipilih. Dari data no.9 diatas dapat dilihat hipnoterapis memberikan decision making atau keputusan dengan penyelesaian masalah yang memungkinkan dari alternatif tersebut.

Hipnoterapis memberikan struktur atau langkah-langkah berpikir dalam pembicaraan untuk menentukan pemecahan masalah. Interpretasi klien dalam mengutarakan isi hatinya, tentang perbuatan, dan perkataannya, kemudian hipnoterapis dapat menggali lebih dalam lagi. Teknik interpretasi ini merupakan lanjutan dari teknik penjelasan. Pada teknik penjelasan ini, hipnoterapis memperjelas lagi pikiran, perasaan yang telah terungkap secara implisit kepada klien. kalau persepsi hipnoterapis tepat, maka klien akan membenarkannya sementara dalam hal ini hipnoterapis tidak menambahkan, tapi hanya memperjelas. Diharapkan klien sudah menyadari pikiran dan perasaannya itu.

Konfrontasi antara klien dan hipnoterapis. Hipnoterapis mengarahkan perbuatan klien atas beberapa hal yang menurut pandangan hipnoterapis tidak sesuai satu dengan yang lainnya. Ketidaksesuaian ini terdapat diantara dua hal yang telah dikatakan oleh klien (tidak konsisten) atau diantara ungkapan verbal dan nonverbal klien atau diantara tindakantindakan dari klien. biasanya klien tidak sadar dengan hal ini, maka tugas hipnoterapis menyadarkan klien, supaya klien menghadapinya dengan lebih jujur.

Hipnoterapis memberikan semacam diagnosa kepada klien tentang apa yang menjadi inti masalah atau mengapa masalah itu timbul. Hipnoterapis memanfaatkan semua data yang diperoleh dan dihubungkan satu dengan yang lainnya.

Pada saat kondisi klien terasa sangat sulit, hipnoterapis dapat memberi semangat dengan cara membesarkan hati, memberikan atau menunjukkan harapan supaya klien tidak kehilangan semangat. Dalam hal ini dituntut kehati-hatian dari hipnoterapis jangan sampai memberikan kepastian yang sebenarnya tidak dapat diberikan, misalnya dengan mengatakan "Pasti semuanya baik".

Penilaian hipnoterapis berdasarkan pertimbangan objektif yang bersifat menolak pandangan, tindakan atau rencana klien. Penilaian ini dapat digunakan kalau hubungan hipnoterapsi dengan klien sudah cukup baik, sehingga komentar negatif tidak akan merusak hubungan, bahkan diharapkan juga dapat membantu klien untuk menghadapi masalahnya dengan lebih realitis lagi.

Setelah melalui proses komunikasi terapeutik, hipnoterapis telah mengetahui apa yang menjadi permasalahan dan mencari solusi yang dapat dilakukan untuk mencapai tujuan. Kemudian, barulah hipnoterapis memberikan sugesti kepada klien untuk menghilangkan hambatan dan memperkuat tujuan yang diinginkan klien dan tentunya keberhasilan dari pemberian terapi ini juga adanya keinginan yang kuat dari klien untuk berubah.

Tahap induksi merupakan tahapan kunci dari hipnotis. Klien akan dibawa dari alam sadar ke alam bawah sadarnya. Proses ini akan membawa klien dari kondisi "beta" ke kondisi "alpha" bahkan "theta". Dalam keadaan ini, klien sepenuhnya dikendalikan oleh hipnoterapis. Bagian utama dari induksi adalah kalimat kunci untuk memerintahkan klien agar tidur. Tahap ini membutuhkan waktu antara 5 menit bahkan ada sampai 30 menit, tergantung dari kondisi si klien. Adapun kata-kata kunci dalam induksi itu berbentuk:

Pacing dan leading merupakan latihan menemukan pengalaman pribadi klien. Hipnoterapis akan memberikan sugesti bahwa klien sedang berada dalam keadaan efek, sehingga perintah selanjutnya akan mudah diterima. 
10. Tutup mata anda dan buatlah diri anda dalam kondisi rileks...

tarik napas yang dalam...

hembuskan... dan tarik napas

lagi...dan hembuskan... dan tarik napas lagi... tahan

beberapa detik dan... hembuskan serta rileks...

Saya akan membuat anda jadi rileks... setiap bagian tubuh anda dari ujung kepala sampai ujung kaki... dan pada setiap bagian tubuh saat anda menjadi rileks

anda...anda dapat beristirahat dengan tenang... saya

ingin anda berimajinasi... lihat yang anda lihat... rasakan

yang anda rasakan...ketika seluruh tubuh anda menjadi

rileks semuanya...anda begitu damai...

Penggunaan kata-kata "saya akan membuat anda menjadi rileks", "saya ingin anda berimajinasi", "ketika seluruh tubuh anda menjadi rileks", membawa pikiran klien secara perlahan-lahan dan halus masuk ke kondisi pikiran bawah sadar beta bahkan theta. Penggunaan kata-kata "rileks", "istirahat" dan "damai" dengan jelas merangsang otak untuk mengaktifkan rasa emosi positif. Dalam kondisi ini klien dengan sangat mudah diberikan sugesti sejauh tidak melanggar nilai-nilai moral, serta etika ataupun kepercayaan dari klien. Pada

klien AM kata "rileks" diganti dengan kata" damai" atau "nyaman" karena ketika hipnoterapis mengucapkan kata "rileks" tidak terdapat reaksi dari klien, oleh karena itu hipnoterapis menukarnya. Semua itu dimungkinkan karena klien AM tidak mengerti dengan arti rileks. Klien AM tumbuh dan berkembang dalam lingkungan yang sederhana sementara penggunaan kata "rileks" di dalam lingkungannya mungkin saja jarang didengar atau bahkan tidak ada sama sekali oleh sebab itu, hipnoterapis menukarnya supaya tidak terjadi kerancuan dalam menyampaikan sugesti. Analisis ini sesuai dengan pernyataan Rakhmat (1994) bahwa bahasa secara fungsional harus dapat dipahami dan semua kalimat yang diberikan dapat dibayangkan serta dimengerti oleh pendengar (klien).

Berdasarkan teori Keraff (1994), didalam menyampaikan bahasa verbal di dalam hipnoterapi dalam hal ini penggunaan kalimat efektif diantaranya harus memiliki kriteria kesatuan ide dan penalaran. Kesatuan ide merupakan kesatuan gagasan atau makna yang dapat dimengerti oleh kedua belah pihak sementara penalaran adalah dapat diterima dan dicerna oleh klien dalam hal ini kata "damai" dan "nyaman" lebih cocok untuk klien AM sementara klien WW dan klien IR lebih cenderung dengan kombinasi pemakaian katakata "rileks", "nyaman", dan "damai".

Disamping penggunaan bahasa kunci, hipnoterapis juga harus memperhatikan elemen lainnya, di antaranya:

\section{Ritme}

Ketika melakukan proses hipnotis, pada umumnya hipnoterapis mengamati keluar masuknya napas klien. Hipnoterapis akan menyelaraskan ucapannya dengan pola napas dari klien dengan mengamati naik turunnya dada atau melihat ujung hidung klien. Hal ini dimaksudkan untuk menyelaraskan sugesti yang diberikan dengan napas klien.

Nada suara hipnotis juga disesuaikan dengan aliran napas klien. Jika aliran napas klien menurun, maka nada suara hipnotis diturunkan juga. Hal ini dimaksudkan untuk memberikan umpan balik di mana dengan memperlambat irama bicara, hipnotis akan memberikan efek menurunkan aliran napas klien. Secara perlahanlahan, hipnotis juga mulai bicara pada kecepatan normal.

\section{Suara hipnotis}

Ada dua cara hipnotis dalam mengucapkan kata-katanya. Cara pertama dengan mengucapkkan kata-kata dengan monoton, di mana ada sedikit perubahan pada nada suara. Hal ini akan meyebabkan pikiran sadar klien menjadi bosan, dan pikiran bawah sadar klien secara perlahan akan menerima perintah-perintah hipnotis. Kedua, dengan mengucapkan kata-kata secara bergelombang, dimana suara hipnotis secara perlahan diatur sehingga menenangkan klien dan masuk kedalam kondisi trans. Kondisi ini akan berkembang 
secara spontan. Sugesti akan mudah diberikan apabila kata-kata yang diucapkan mengalir dengan tenang, jelas, tampa gelisah, serta kepercayaan yang tinggi dari hipnoterapis.

Hipnoterapis memberikan semacam sugesti dengan mengacaukan pikiran sadar klien dengan maksud melampaui kemampuan kritis dari klien:

11. Anda sekarang berada dalam gedung berlantai $10 \ldots$ dan anda tengah bersiapsiap turun kelantai daar dengan menggunakan lift... anda sekarang berada dalam lift... dan tekanlah tombol angka sepuluh... rasakan setiap lift turun, anda merasa rileks...rasakan lift bergerak turun.... sembilan...rasakan anda semakin rileks... delapan...

Dengan cara menghitung, pikiran klien akan banyak diserap oleh konsentrasi dan pikiran bawah sadar. Pikiran sadar akan diambil alih oleh penghitungan ini, maka pikiran sadar akan kurang mampu menemukan sugesti-sugesti hipnotis yang diberikan. Dengan menyuruh klien merasakan rileks disetiap penurunan lift juga akan memfokuskan pikiran bawah sadar klien terhadap sugesti. Klien disini lebih mengaktifkan suatu sensasi dibandingkan suatu gambaran. Dengan perintah untuk menvisualisasikan setiap angka yang dihitung juga membantu pikiran untuk tidak menghiraukan suara (gangguan) dari luar.

Teknik mengambil pikiran sadar ini dilakukan kepada Klien WW karena klien WW sedikit mengalami kesulitan untuk dapat masuk ke dalam kondisi trans. Diberikannya teknik ini agar klien WW tidak dapat fokus ke pikiran sadarnya dan diharapkan dapat berkonsentrasi ke perintah hipnoterapis untuk dapat masuk ke pikiran bawah sadarnya agar dapat segera msuk ke kondisi trans seperti yang diharapkan.

Walaupun pikiran telah difokuskan, namun pikiran sadar masih dapat "mendengar" dalam kondisi induksi ini. Dalam kondisi induksi, pemberian kata-kata yang membingungkan akan dapat membebani pikiran sadar klien. Pemberian sugesti seperti:
12. Saya akan menghitung mundur dari 10 hingga 1 ...rileks... dan dengan setiap hitungan... gandakan releksasi anda... sehingga

pada hitungan ke $1 \ldots$ anda akan tertidur 10 kali lebih lelap

lagi... 10, 9,8,7,6,5,4,3,2,1... tidur 10 kali lebih lelap lagi...

Dengan perintah hitungan untuk menggandakan rileksasi, pikiran sadar dapat rileks dengan mudah dan makin mudah lagi. Cara ini merupakan jalan keluar yang diambil pikiran sadar. Pemberian sugesti seperti "rileks" atau "tertidur 10 kali lebih lelap lagi" yang diucapkan dengan memberikan jeda waktu yang singkat akan berefek memisahkan perintah dari kata-kata berikutnya, walaupun itu hanya dapat dipahami dengan pikiran bawah sadar saja.

Teknik ini efektif dilakukan pada klien IR karena klien IR mendapati kendala dalam memasuki kondisi trans. Dengan membebani pikiran sadar klien, klien tidak dapat berpikir kritis lagi dan perintah yang membingunkan tersebut membuat klien tidak dapat berpikir kritis lagi. Dilihat dari penggunaan kalimat-kaliamat yang diberikan hipnoterapis kepada klien WW dan klien IR mempunyai makna yang sama yaitu bermakna sama-sama menggandakan perasaan rileksasi. Perbedaanya hanya terletak pada variasi penggunaan bahasa saja.

Menurut Keraff (1994) variasi kalimat diperlukan untuk menarik perhatian klien dengan cara memberikan kalimat yang beragam, bersinonim atau berbentuk frase dan mengubah posisi kalimat. Hal ini dimaksudkan untuk menghindari kemonotonan didalam berbahasa.

Imajinasi berasal dari pikiran bawah sadar, dengan memerintahkan klien untuk melakukan visualisasi akan mendorong klien melepaskan pikiran sadarnya yang bersifat analitis dan kritis dalam dukungannya terhadap sesuatu yang berharga. Sugesti itu dapat berupa:

13. Saya minta anda membayangkan bahwa anda berada pada

tempat yang menyenangkan dan nyaman bagi anda... tempat itu boleh saja di alam terbuka... pegunungan... pantai... atau bahkan kamar anda sendiri... 
Baiklah... pada hitungan $10 \ldots$ anda mulai membayangkan tempat yang anda sukai... 9... rasakan tempat tersebut semakin jelas... 8... tempat

tersebut semakin nyata... 7... anda

benar- benar dapat merasakan berada disitu... $6 \ldots$ anda benar-benar

mulai dapat mengamati keadaan sekeliling... $\quad 5 \ldots$ semakin nyata dan semakin jelas... 4... anda benarbenarmenikmatinya... $3 \ldots$ rasakan hal ini sangat nyata... $2 \ldots$ anda menikmati berada disitu... $1 \ldots$ silakan anda merasakannya... sangat jelas...sangat nyata... dan anda sangat

menyenanginya...

Hipnoterapi memberikan sugesti pada klien untuk memilih tempat yang membuat klien nyaman, hal ini dimaksudkan agar klien dapat menvisualisasikan rasa nyaman yang bisa dinikmati klien dengan baik. Kata-kata yang dipakai dapat mengaktifkan sistem lain dalam otak dimana berhubungan dengan perasaan yaitu perasaan nyaman. Dengan demikian, sugesti untuk merasakan rileksasi berjalan sesuai dengan yang dikehendaki yaitu untuk melangkah ke tahap yang berikutnya yaitu Deepening.

Deepening bertujuan untuk membimbing klien secepat mungkin kedalam kondisi trans dalam atau somnambulisme karena, sugesti yang yang diberikan kepada klien dalam kondisi somnambulisme paling efektif dan bertahan lebih lama dibandingkan kalau diberikan ketika klien masih berada dalam kondisi trans ringan. Teknik pendalamnan ini diberikan dengan cara sangat halus, sangat lembut, dan sangat tersembunyi namun sangat powerfull (berdaya guna) yang menyusup kedalam pikiran bawah sadar klien.

Dalam kondisi deepening ini juga bisa dilakukan uji kedalaman trans dengan cara menjatuhkan tangan klien apakah sudah sangat lemas atau masih kaku. Jika masih kaku akan dilakukan deepening (pendalaman) secara langsung dengan perintah:

14.Lemaskan tangan anda... sungguhsungguh lemas... sehingga tangan anda benar-benar ibarat kain basah yang ketika dijatuhkan akan jatuh lemas dan tak bertenaga... dan ketika saya jatuhkan... kirimkan gelombang rileks keseluruh tubuh anda... dari ujung kaki ke ujung kepala... dan ketika anda telah melakukan itu... anda merasakan seluruh tubuh anda menjadi rileks daripada yang sebelumnya.

Tujuan dari pemberian sugesti di atas adalah untuk mengantarkan klien benar-benar dalam keadaan rileks. Pemberian kata-kata tersebut di atas dimaksudkan untuk meminta klien mengistirahatkan pikirannya, melemaskan semua pembuluh darah, dan pembuluh syarafnya dengan demikian klien akan masuk kedalam trans dalam.

Suggestion merupakan tahap inti dalam hipnoterapi. Pada kondisi ini klien telah memasuki kondisi trans yang sangat dalam atau somnambulisme dan kondisi ini akan dimanfaatkan hipnoterapis untuk memberikan sugesti-sugesti positif yang bersifat untuk mengobati masalah klien. Sugesti-sugesti ini diharapkan akan tertanam pada pikiran bawah klien dan menghasilkan perubahan positif.

Dalam penelitian ini, objek penelitian merupakan pecandu rokok, maka sugesti-sugesti yang diberikan berupa motivasi-motivasi untuk menghilangkan kebiasaan buruk dan diharapkan klien dapat hidup dengan sehat atau sesuai dengan yang diinginkan yaitu kesembuhan dari masalah yang diderita.

Pemberikan sugesti pada tahap ini, kalimat yang disampaikan hipnoterapis dibuat dengan:

1. Menggunakan kalimat efektif dengan penyampaian yang sederhana, singkat, dan sesuai dengan umur, pendidikan serta lingkungan klien. Agar klien bisa mengerti sugesti yang diberikan hipnoterapis dan bisa fokus pada masalah yang dihadapinya, pemberian bahasa untuk klien AM berbeda dengan klien IR dan WW.

Bahasa yang dipakai kepada klien AM lebih sederhana dan cendrung menghindari istilah-istilah yang rumit. Seperti pemakaian istilah-istilah zat-zat kimia yang terkandung dalam rokok. Penggunaan istilah "nikotin" diganti dengan "racun yang mematikan" 
2. Sugesti diberikan secara berulang, agar sugesti tertanam kuat pada pikiran bawah sadar klien. Sugesti ini dapat diulang dalam beda bentuk yaitu dengan maksud yang sama tapi dengan cara yang berbeda atau sinonim yang sama dan menggunakan kata yang berbeda.

Seperti perumpamaan rokok diibaratkan sama dengan 15. "tikus" untuk klien WW dan 16. "belatung" untuk klien AM serta 17. "ular" untuk klien IR. Penggunaan sinonim hewanhewan tersebut berdasarkan kepada ketidaksenangan masing-masing klien terhadap hewan itu, dan diharapkan perumpamaan itu akan tertanam dipikiran bawah sadar mereka bahwa rokok identik dengan hewan-hewan yang menjijikkan sehingga mereka akan menghindari untuk merokok.

3. Sugesti dibuat semenarik mungkin dan dapat dipercaya, agar klien tidak menolak sugesti yang diberikan dan mau bekerjasama. Pada klien WW diperintahkan untuk mengimajinasikan hidup bahagia ditengah-tengah anak-anak yang mencintainya, klien IR disugestikan untuk mendapatkan masa depan yang cerah dan sukses, dan pada klien AM berisikan sugesti hidup dengan senang dengan banyak teman dan dicintai kedua orang tuanya.

4. Fokus pada satu tujuan, agar pikiran klien tidak terpecah pada masalah yang lain. Dalam hal ini untuk berhenti merokok dan hidup dengan sehat.

5. Menggunakan kalimat positif, sugesti yang diberika sedapat mungkin menghindari kata-kata seperti, "saya tidak dapat", "saya tidak bisa", "saya tidak ingin" karena pikiran bawah sadar tidak dapat menerima kalimat negatif.

6. Tetap mempertahankan memberikan sugesti rileksasi secara umum dan tidak menggunakan kata-kata yang memprovokasi agar tidak menimbulkan ketakutan dan kekhawatiran klien.

7. pemberian sugesti yang berulang (Law of Compounding Suggestion). Dalam pengobatan melalui hipnoterapi, dibutuhkan minimal $3-7$ kali pertemuan, ini dimaksudkan agar sugesti yang diberikan dapat tertanam kuat di pikiran bawah sadar klien.

Masuknya sugesti dengan cepat juga tergantung kepada seberapa dalam kerjasama klien bisa memasuki pikiran bawah sadarnya. Kemampuan imajinasi klien sangat berperan sekali, semakin kuat imajinasi klien mencapai tujuannya, maka semakin cepat juga otak akan bekerja untuk mewujudkannya.

Agar sugesti dapat bertahan lama atau permanen di pikiran klien, digunakan teknik Direct Drive yaitu dengan cara meminta klien mengulangi kata-katanya berkali dalam hati, sangat disarankan adalah 15 kali pengulangan dengan berteriak dalam hati. Ini dimaksudkan agar sugesti dapat dirasakan lebih kuat lagi. Adapun Direct Drive sugesti itu adalah:

18. Sekarang saya akan mengajari anda bagaimana caranya mempengaruhi semua pikiran dan bagian dari pikiran anda... saya akan memberikan sebuah sugesti kepada anda... saya

menginginkan anda untuk berteriak dengan keras tetapi didalam hati anda saja... setiap saya meminta anda melakukan... anda berteriak

sangat keras didalam hati anda... Sekarang silakan tirukan saya... Sekarang saya orang yang percaya diri sepanjang hidup dan hidup sehat,

bebas rokok ... silakan teriak dengan keras didalam hati anda...Lagi..Sekarang saya orang yang percaya diri sepanjang hidup saya dan hidup sehat bebas rokok...silakan teriak dengan keras

dalam hati anda...

Lagi... (ulangi minimun 15 kali)

Adanya perintah "teriak" akan mengaktifkan sensori audiotori atau indera pendengaran. Bila klien sudah melakukan perintah Direct Drive ini, maka klien bisa membuka mata, tetapi klien masih didalam kondisi hipnosis, dan masih diberikan sugesti berupa:

19. Tatap mata saya... sekarang anda menjadi orang yang percaya diri dan tetap menjadi orang yang percaya diri disepanjang hidup anda... dan tolak orang yang mempengaruhi anda untuk membuat anda menjadi orang yang berpenyakitan... 
Maksud hipnoterapis menyuruh klien menatap mata hipnoterapis supaya klien masih tetap fokus dan masih tetap dibawah kontrol hipnoterapis. Penggunaan kata-kata "tetap" dan "percaya diri" untuk mempertegas sugesti tertanam baik di pikiran bawah sadar. Setelah dirasakan klien cukup mendapatkan sugesti, maka terapi dilanjutkan lagi ke tahap Emerging.

Emerging, tahap ini merupakan akhir dari hipnoterapi, hipnoterapis akan membangunkan klien dari tidur hipnosisnya. Klien akan akan dikembalikan lagi ke kondisi normal. Pemberian sugesti berupa:

20.Sebentar lagi... saya akan menghitung angka dari satu hingga ketiga...pada hitungan ketiga... andaakan membuka mata anda dan merasakan dalam kondisi segar... benar- benar sadar secara total... dan merasakan betapa luar biasanya...Satu... pelan-pelan dengan begitu mudahnya anda merasakan kembali menuju kesadaran sempurna...Dua... anda mulai menyadari kesadaran anda dan betapa luar biasanya perasaan dengan energi baru yang mengalir keseluruh pikiran dan tubuh anda.. dan anda merasakan mata anda seperti dibersihkan... seperti habis dibersihkan dengan hawa pegunungan yang menyejukkan... dan pada hitungan berikutnya... mata anda akan terbuka... sadar secara sepenuhnya... betapa luar biasanya setiap yang anda alami..Sekarang bersiap-siap.... tiga... buka mata anda... dan sadar secara sepenuhnya... anda menyadari betapa gembiran perasaan anda...bagaimana perasaan anda... Sangat luar biasa...

Hipnoterapis mengaktifkan kesadaran klien kembali ke kondisi normal. Dengan perintah membuka mata, klien akan sadar dengan sendirinya. Kata-kata "segar", "kesadaran sempurna" akan mengaktifkan perasaan nyaman dan stabil dengan seutuhnya. "Energi baru", dan "hawa pegunungan yang menyejukkan" akan menimbulkan sensasi emosi yang penuh semangat dan mengaktifkan visual yang bisa membangkitkan sistem yang berkaitan dengan sentuhan kenyamanan.

Sebagai penutup, untuk mengunci sugesti yang diberikan berjalan dengan sempurna, hipnoterapis memberikan kalimat penegas

21."sangat luar biasa" ini dimaksudkan untuk menambah keyakinan klien bahwa mereka telah menjadi sesuatu yang luar biasa dan telah menjadi sesuatu yang menjadi lebih baik. Penegasan kalimat "sangat luar biasa" dapat diartikan juga sebagai suatu stempel penutup bahwa terapi telah dilakukan dengan sempurna.

\section{KESIMPULAN}

Agar sugesti bisa diterima dan bermanfaat bagi klien, maka sugesti haruslah memiliki kriteria sebagai berikut:

1.bahasa yang digunakan merupakan kalimat efektif, singkat dan jelas, mudah dipahami oleh klien, bahasa yang digunakan disesuaikan dengan tingkat intelektual klien karena masing-masing orang mempunyai tingkat pemahaman yang berbeda-beda juga.

2. Kalimat yang disampaikan memiliki arti tunggal, yaitu memiliki satu arti dan menghindari kiasan. Pikiran bawah sadar dapat menerima informasi apapun hanya dalam bentuk mentah dan tidak dijabarkan lagi.

3. Menggunakan kalimat aktif yaitu kalimat yang berorientasi hasil dan menghindari penggunaan kata-kata "jangan", "akan", "bukan", "tidak". Pikiran bawah sadar bersifat tidak mau mencerna bahasa yang diberikan, jadi bahasa yang didengar langsung disimpan dipikiran bawah sadar sebagai apa yang dimaksudkan. Contohnya " mulai sekarang saya bukan perokok lagi", kalimat ini akan diterima oleh pikiran bawah sadar sebagai "mulai sekarang saya perokok". 
4. Menggunakan kata sekarang, pikiran bawah sadar mempunyai sifat tidak mau menganalisa lagi dan tergesa-gesa dalam menghadapi masalah. Pikiran bawah sadar selalu membutuhkan solusi "sekarang juga" tampa melihat dampak solusi tersebut dimasa mendatang. Untuk mempermudah penerimaa pikiran bawah sadar sebaiknya diawali dengan kaliamat: "mulai sekarang", "anda sudah", "anda sedang", penggunaan kata-kata tersebut dimaksudkan untuk mewujudkan suatu proses penyelesaian masalah atau bahkan sudah terselesaikan.

5. Kalimat-kalimat yang disampaikan mengandung arti menguntungkan bagi klien, karena sudah jadi watak manusia untuk menguntungkan dirinya, dan menghindari kerugian oleh karena itu sugesti dibuat agar klien merasa diuntungkan.

6. Kalimat sugesti disampaikan dengan berulang, supaya sugesti lebih mempunyai pengaruh yang kuat dan mendapatkan hasil yang maksimal.

7. Kalimat sugesti yang disampaikan berisi kepastian dan menimbulkan harapan nyata, menghindari penggunaan kata-kata "mungkin", "seandainya", "mudah mudahan", "semoga".

8. Isi sugesti sesuai dengan kebutuhan klien, yaitu sugseti positif untuk mencapai suatu tujuan, Sebelum memberikan hipnoterapi, hipnoterapis terlebih dahulu harus melakukan pendekatan terhadap klien untuk mengetahui masalah yang melatar belakanginya atau melakukan pendekatan dengan komunikasi terapeutik. Ini penting karena didalam pemberian hipnotis dibutuhkan suatu keyakinan klien supaya klien bisa masuk kedalam trans (pikiran bawah sadar) dengan mudah.

Proses dari hipnoterapi itu sendiri terdiri dari, pemberian Induksi, Deepening, Suggestion, dan Emerging. 


\section{DAFTAR PUSTAKA}

Al Firdaus, Iqra. 2012. Kunci-kunci Kontrol Emosi dengan Otak Kanan dan Otak Kiri. Yogyakarta: Diva Press.

Arif, Antonius. 2011. The Handbook Hypnotherapy Scripts and Strategies. Jakarta: PT Elex Media Komputindo.

Arifuddin. 2010. Neurospikolinguistik. Jakarta: Rajawali Press.

Amen , Daniel G. 2011. Change Your Brain Change Your Life. New York: Three Rivers Press.

Bandler dan Grinder. 1975. Structure of Magic. Meta Press.

Becker, Jordy. 2008. Tips Cerdas Agar Anak Anda Berhenti merokok. Jakarta: Prestasi Pustaka.

Begley, Sharon. 2011. Train Your Mind Change Your Brain. Jakarta: PT Buana

Ilmu Populer.

Car, Allen. 2010. Cara Mudah Berhenti Merokok. Jakarta: Opus.

Chaer, Abdul. 2002. Psikolinguistik Kajian Teoretik. Jakarta: rineka Cipta.

Dharmaperwira, Reni. 2004. GangguanGangguan Komunikasi pada Disfungsi Hemisfer Kanan dan Pemeriksaan Komunikasi Hemisfer Kanan (PKHK). Jakarta: Ikrar Mandiriabadi.

Ericson. 1954. Time Distortion in Hypnosis. Meta Press.
Maleong, Lexy J. 1996. Metode Penelitian Kualitatif. Cetakan ke 7. Bandung: PT Remaja Rosdakarya.

Mahsun. 2005. Metode Penelitian Bahasa. Jakarta: PT Raja Grafindo Persada.

Mulyodiharjo, Sumartono. 2002. The Power of Cmmunication. Jakarta: PT

gramedia.

Morgan, Dylan. 2011. Hipnosis for Beginners. Yogyakarta: Lahar Publisher.

K, Obler Oraine, Gjerlow Kris. 2000. Language and the Brain. New Jersey: Cambrige University.

Krishnamurti. 2012. NLP ala Backpacker. Yogyakarta: Pohon Cahaya.

Ramadhani, Nurul.2010. NLP Neuro Linguistik Programming. Bandung: alfabeta

Sastra, Gusdi. 2011. Neurolinguistik Suatu Pengantar. Bandung: Alfa

BetaDharmaperwira, .

Sudaryanto. 1993. Metode dan Aneka Teknik Analisi Bahasa. Yogyakarta: Duta Wacana University Press.

Susilo, Adhi. 2010. Hipnotis Metode Terapi untuk Kesuksesan Karier dan menghilangkan Kebiasaan Buruk dengan Hipnoterapi. Jakarta: Gudang Ilmu.

Suwandi, Awie. 2013. Turbo Speed Hipnotis. Jakarta: Titik Media Publisher.

Telushkin, Joseph. 1996. Kata-kata Dasyat yang Menyembuhkan. Jakarta: PT Buana Ilmu Populer. 